\title{
Some Features of Prostaglandin Synthesis of the Cancer Cells Metastasized into Liver from Gastric Cancer Lesions
}

\author{
Ichiro Nakazawa, Masamoto Iwaizumi* and Kazuo \\ OHUCHI $\dagger$ \\ The Third Department of Internal Medicine, Tohoku \\ University School of Medicine, *The Institute for Chemical \\ Reaction Science, and $\dagger$ Department of Biochemistry, Faculty \\ of Pharmaceutical Sciences, Tohoku University, Sendai 980
}

\begin{abstract}
Nakazawa, I., Iwaizumi, M. and Ohuchi, K. Some Features of Prostaglandin Synthesis of the Cancer Cells Metastasized into Liver from Gastric Cancer Lesions. Tohoku J. Exp. Med., 1993, 170 (1), 59-61 — In order to study the mechanism of cancer metastasis, AH100B rat hepatoma cells were transplanted to the stomach of male Donryu rats. Each hepatic metastatic nodule was collected with the respective primary gastric lesions. Each sample thus obtained was injected separately into the peritoneal cavity of male Donryu rats to make free cancer cells; then, intact cancer cells of the hepatic metastatic and primary gastric lesions were collected. After washing in Dulbecco's phosphate-buffered saline $\left(\mathrm{Ca}^{2+}\right.$ and $\mathrm{Mg}^{2+}$-free, $\mathrm{pH}$ 7.2), the definite number of the metastatic and primary gastric cancer cells were incubated in the phosphate-buffered saline containing $\left[1{ }^{14} \mathrm{C}\right]$ arachidonic acid at $25^{\circ} \mathrm{C}$ for $30 \mathrm{~min}$. Arachidonic acid metabolites formed during the incubation period were extracted and subjected to thin-layer chromatography, followed by autoradiography. Each radioactive spot was scraped off the plate and measured for its radioactivity. The pattern of the ability to produce PGs was different between the cancer cells which metastasized to the liver and those of the primary lesions, that is, percentage of $\mathrm{PGF}_{2 \alpha}$ was higher $(p<0.05)$ and that of $\mathrm{PGE}_{2}$ was quite higher $(p<0.01)$ in the hepatic metastatic cancer cells as compared with those of the primary gastric lesion. These results suggest that PGs produced by hepatic metastatic cancer cells might play an important role in hepatic metastatic formation. —_ cancer metastases; liver; gastric cancer
\end{abstract}

We have been investigating features of prostaglandin (PG) synthesis of the metastatic cancer cells, using an animal model in which AH100B (a rat hepatoma cell line) cells were injected into the carotid artery of male Donryu rats (Nakazawa et al. 1985, 1989, 1991). In this paper, we will deal with some features of $P G$ synthesis in cancer cells metastasized into the liver from the gastric cancer lesion.

\section{Materials and Methods}

Experimental animals. Donryu male rats (Nihon Rat Co. Ltd., Urawa) weighing 100 to $120 \mathrm{~g}$ were used and fed with a pellet diet, NF (Oriental Yeast Co. Ltd., Tokyo).

Tumor. AH100B ascitic hepatoma cells were obtained from the Department of

Received December 16, 1992; revision accepted for publication April 3, 1993. 
Oncology, the Research Institute for Tuberculosis and Cancer, Tohoku University. After they were treated as described previously (Nakazawa et al. 1991), $2 \times 10^{6}$ cancer cells were suspended in $0.1 \mathrm{ml}$ of a sterilized physiological saline and transplanted to the glandular stomach of each rat. About 4 weeks later, the rats were sacrificed under diethylether anesthesia, and white metastatic nodules in the liver sized $1 \mathrm{~mm}$ or less in a diameter and the gastric tumor tissues were collected. Each sample was pathohistologically examined and determined the ability to produce $\mathrm{PGs}$ according to the procedure described previously (Nakazawa et al. 1991). Further details for obtaining the intact free cancer cells was described elsewhere (Nakazawa and Iwaizumi 1982).

Experimental procedure for prostaglandin synthesis. Metastasized cancer cells into the liver and the cancer cells of the gastric tumor were suspended in Dulbecco's phosphatebuffered saline (PBS) $\left(\mathrm{Ca}^{2+}\right.$ and $\mathrm{Mg}^{2+}$-free, $\mathrm{pH} 7.2$, Gibco, Long Island, NY, USA) at $2 \times 10^{7}$ cells per $\mathrm{ml}$. Then, each cell suspension containing $1 \times 10^{6}$ cancer cells was mixed with 50 $\mu 1$ of the PBS containing $0.2 \mu \mathrm{Ci}$ of $\left[1{ }^{14} \mathrm{C}\right]$ arachidonic acid (AA) (New England Nuclear, Boston, MA, USA) and incubated at $25^{\circ} \mathrm{C}$ for $30 \mathrm{~min}$. After the incubation, PGs formed were extracted and separated by means of thin-layer chromatography (TLC) as described previously (Nakazawa et al. 1989). As authentic samples, AA (Merk, Germany), 6-ketoprostaglandin $\mathrm{F}_{1 \alpha}\left(6\right.$-keto- $\left.\mathrm{PGF}_{1 \alpha}\right)$, prostaglandin $\mathrm{F}_{2 \alpha}\left(\mathrm{PGF}_{2 \alpha}\right)$, prostaglandin $\mathrm{E}_{2}\left(\mathrm{PGE}_{2}\right)$, prostaglandin $\mathrm{D}_{2}\left(\mathrm{PGD}_{2}\right)$ and thromboxane $\mathrm{B}_{2}\left(\mathrm{TXB}_{2}\right)$ (Ono Pharmaceutical Co. Ltd., Osaka), $5 \mu \mathrm{g}$ each per plate, were used. TLC plates were subjected to autoradiography at $4^{\circ} \mathrm{C}$ for 2 weeks. Whole radioactive spots, including those corresponding to authentic standards, were scraped off the plate separately, and each radioactivity was measured using a liquid scintilation counter (LSC 1000, Aloca Co. Ltd., Tokyo) as described previously (Nakazawa et al. 1991).

\section{Results and Discussion}

Conversion of $\left[1{ }^{-14} \mathrm{C}\right] \mathrm{AA}$ into each $\mathrm{PG}$ was examined by incubating the cells at $25^{\circ} \mathrm{C}$ for 15,30 and $60 \mathrm{~min}$. Since the conversion rate reached a plateau at $30 \mathrm{~min}$, following experiments were performed by incubating the cells for $30 \mathrm{~min}$ at $25^{\circ} \mathrm{C}$. In the incubation for $30 \mathrm{~min}, 52.2 \%$ of $\left[1-{ }^{14} \mathrm{C}\right] \mathrm{AA}$ was metabolized. Table 1 shows percentage of radioactivity of 6-keto- $\mathrm{PGF}_{1 \alpha}, \mathrm{PGF}_{2 \alpha}, \mathrm{TXB}_{2}, \mathrm{PGE}_{2}$ and $\mathrm{PGD}_{2}$ synthesized by the cancer cells metastasized into the liver and the cancer cells of the gastric tumor. The percentage was

TABLE 1. Pattern of prostaglandin synthesis of AH100B cancer cells metastasized to the liver and of the primary gastric lesion ${ }^{\mathrm{a}}$

\begin{tabular}{lccc}
\hline Prostaglandins & $\begin{array}{c}\text { Cancer cells } \\
\text { metastasized into } \\
\text { liver }\end{array}$ & $\begin{array}{c}\text { Cancer cells } \\
\text { transplanted to } \\
\text { stomach }\end{array}$ & $P^{\mathrm{b}}$ \\
\hline 6 -keto-PGF ${ }_{1 \alpha}$ & $3.40 \pm 1.27$ & $4.13 \pm 1.44$ & n.s. \\
$\mathrm{PGF}_{2 \alpha}$ & $4.85 \pm 1.58$ & $1.13 \pm 0.23$ & 0.05 \\
$\mathrm{TXB}_{2}$ & $16.34 \pm 2.97$ & $19.32 \pm 4.86$ & n.s. \\
$\mathrm{PGE}_{2}$ & $2.49 \pm 0.50$ & $0.81 \pm 0.31$ & 0.01 \\
$\mathrm{PGD}_{2}$ & $2.19 \pm 0.40$ & $2.73 \pm 1.66$ & n.s. \\
\hline
\end{tabular}

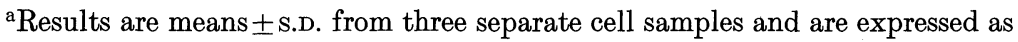
percentages of the total radioactivity recovered. Percentages were calculated as described in the text. There were no significant differences in total radioactivity recovered from the TLC plate between the cancer cells metastasized into liver $(25,500 \pm 1,580 \mathrm{dpm}$, mean \pm s.D. $)$ and the primary lesion $(24,600 \pm 1,670 \mathrm{dpm})$.

${ }^{\mathrm{b}} P$ values were analyzed by Student's $t$-test; n.s., not significant. 
calculated as follows:

$$
\text { Percentage }=\frac{\text { Radioactivity of each spot recovered from the TLC plate }}{\text { Total radioactivity recovered from the TLC plate }} \times 100
$$

The percentage of $\mathrm{PGE}_{2 \alpha}$ and $\mathrm{PGF}_{2}$ in the cancer cells metastasized into the liver was significantly higher than the corresponding percentage of the cancer cells of the gastric tumor. $\mathrm{PGE}_{2}$ has diverse kinds of biological activities. Above all, the immunosuppressive action would be the most important for cancer metastatic formation. The immunosuppressive state frequently observed in tumor bearers is reported to be due to $\mathrm{PGE}_{2}$ secreted by tumor cells and the host macrophages acting to suppress T-lymphocytes and NK activities (Jessup et al. 1985; Young et al. 1986). In addition, NK cells are important for limiting cancer metastatic formation (Wiltrout et al. 1985). $\mathrm{PGF}_{2 \alpha}$ also has many kinds of biological activities. $\mathrm{PGF}_{2 \alpha}$ is one of competence factors in Swiss 3T3 cells (Macphee et al. 1984; Macara 1985) and enhances epidermal growth factor (EGF)-stimulated expression of c-myc in Balb/c 3T3 fibroblasts (Handler et al. 1990). The results obtained here suggest that $\mathrm{PGs}$ produced by the cancer cells metastasized into liver might play an important role in cancer metastatic formation. Further study, however, is necessary to clarify the role of $\mathrm{PGs}$ produced by the metastatic cancer cells in the cancer metastatic formation.

\section{Acknowledgments}

This work was supported in part by a Grant-in-Aid for General Scientific Research (58570303, 01570375 and 04670405) to I.N. from the Ministry of Education, Science and Culture of Japan.

\section{References}

1) Handler, J.A., Danilowicz, R.M. \& Eling, T.E. (1990) Mitogenic signaling by epidermal growth factor (EGF), but not platelet-derived growth factor, requires arachidonic acid metabolism in BALB/c 3T3 cells. Modulation of EGF-dependent c-myc expression by prostaglandins. J. Biol. Chem., 265, 3369-3673.

2) Jessup, J.M., Legrue, S.J., Kahan, B.D. \& Pellis, N.R. (1985) Induction of suppressor cells by a tumor-derived suppressor factor. Cell. Immunol., 93, 9-25.

3) Macara, I.G. (1985) Oncogene, ions and phospholipid. Am. J. Physiol., 248, C3-C11.

4) Macphee, C.H., Drummond, A.H., Otto, A.M. \& Asua, L.J. (1984) Prostaglandin $F_{2 \alpha}$ stimulates phosphatidylinositol turnover and increases the cellular content of 1, 2-diacylglycerol in confluent resting Swiss 3T3 cells. J. Cell. Physiol., 119, 35-40.

5) Nakazawa, I. \& Iwaizumi, M. (1982) A correlation between cancer metastases and the fluidity of cancer cell membrane. Tohoku J. Exp. Med., 137, 325-328.

6) Nakazawa, I., Ohuchi, K., Watanabe, M. \& Tsurufuji, S. (1985) A difference in prostaglandin $\mathrm{E}_{2}$ synthesis between cancer cells metastasizing into liver and kidney. Prostaglandins Leukot. Med., 17, 265-266.

7) Nakazawa, I., Iwaizumi, M. \& Ohuchi, K. (1989) Some features of the metastatic cancer cells in prostaglandin production. Tohoku J. Exp. Med., 159, 75-78.

8) Nakazawa, I., Iwaizumi, M. \& Ohuchi, K. (1991) A difference in prostaglandinproducing ability between cancer cells metastasized into liver and kidney. Tohoku $J$. Exp. Med., 165, 229-304.

9) Wiltrout, R.H., Herberman, R.B., Zhang, S.R., Chirigos, M.A., Ortaldo, J.R., Grenn, K.M., Jr. \& Talmadge, J.E. (1985) Role of organ-associated NK cell in decreased formation of experimental metastases in lung and liver. J. Immunol., 134, 4267-4275.

10) Young, M.R., Wheeler, E. \& Newby, M. (1986) Macrophage-mediated suppression of natural killer cell activity in mice bearing Lewis carcinoma. J. Natl. Cancer Inst., 76, $745-750$. 